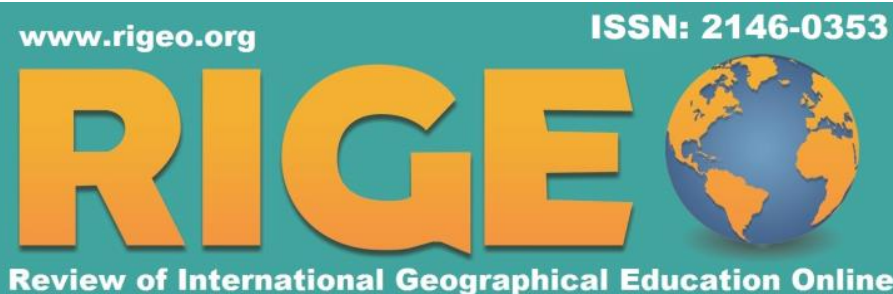

Review of International Geographical Education Online (c)RIGEO Volume 9, Number 1, 2019

Research Article

Copyright @ RIGEO 2019

To cite this article: Kaya, N. (2019). Linking Learning Geography and Teaching Geography: The Gap between School and University in Turkey. Review of International Geographical Education Online (RIGEO), 9(1), 102-121. Retrieved from http://www.rigeo.org/vol9no1/Number1Spring/RIGEO-V9-N1-5.pdf DOI: $10.33403 /$ rigeo.546813

\title{
Linking the Learning and Teaching Geography: The Gap between School and University in Turkey
}

\author{
Niyazi KAYA ${ }^{1}$ \\ Ministry of National Education, Ankara, TURKEY
}

\begin{abstract}
This study was carried out with the aim to determine the level of sufficiency of the geography teachers' education, which they received during their undergraduate education, in terms of their professional performance in the official secondary education institutions under the Ministry of National Education in Turkey. This study adopted the survey model and the relevant data was collected by using a descriptive approach. THESE data were collected from the actively-working geography teachers by using a data collection tool developed by the researcher with the modeling technique to be analyzed and interpreted. According to the results obtained from the collected data; it has been observed that the geography teachers did not consider the undergraduate education they received while carrying out their education activities and they did not have sufficient level in acquiring some of the fields that have to be given to the students. Undergraduate geography teacher programs need to be updated on a need-based basis by taking the opinions of all stakeholders, to be able to apply the geography curriculum effectively and effectively and to provide the geographic skills required by the 21 st century to students. In addition, some suggestions can be made to the geography teachers who are currently working in the Ministry of National Education (MoNE) by developing application-based activities to meet the professional development needs in the areas they need.
\end{abstract}

\section{Keywords}

Undergraduate Geography Education, Geography Teacher, Geography Education, Turkey

"A very good curriculum is useless, if the teacher is not good; it is possible to work with a poor curriculum, if the teacher is good" (A. Becker, 1932).

1Dr., Ministiry of Natioal Education, Ankara Bulvarı, No, 98 Çankaya, Ankara, Turkey. E-Mail: niyakaya [at] gmail.com. ORCID: 0000-0003-2396-7575 
The teaching profession is as old as human history, throughout which it followed a different path of progress for each distinct society and culture. (Aladağ, 2003, p. 7). According to the article 43 of the National Education Basic Law no 1739, teaching is defined as a profession requiring specialization to perform the duties relating the state's education, training and management.

There are three main factors influencing the quality of education: teacher, student and curriculum. The most significant of these factors is the teacher. Also, it is critical that the teacher to lead the effective learning has received a good pedagogical formation as well.

In the section "Qualifications of Teacher" of his book, Sönmez (1994, p. 108) emphasized that "teaching is a significant profession requiring special knowledge and skills, and the teacher has to guide, act like a consistent conductor in the educational environment, they have to be the one who make them find, do and solve instead of the one who transfer, find and do, they have to bear in mind all the time that each student is unique, they need to consider individual differences, to organize the educational environment accordingly, and to follow the new multi-option education methods to enable their students to develop their skills".

Teaching is such a complex specialization that you need to have the ability to consider the process of teaching and the students as a whole besides the knowledge (Aladağ, 2003, p. 8). The teacher is a significant person implementing the state's education policies developed by the studies, influencing such policy with the implementation results, making use of specialization studies and researches in the field of education, but bringing problems for these studies as well. The teacher is a person not only transferring information in a sufficient way but also taking an effective role in education and organizing activities that make a great contribution to the students' success thanks to their behaviors and attitudes (Varış, 1988, p. 117).

"A good teacher knows that the participation or testing period required to teach a specific element varies from a student to another. Some students can learn an element with less effort, while others may need more time and effort to properly learn the same element. Some students can learn the whole process with less effort and time, while others may need to learn each stage of such process by trying one by one and then try to comprehend the whole process" (Bloom, 2012, p. 114).

Today, teachers must possess the mental and educational competencies that will allow them to evaluate, select and synthesize the information and earnings students acquire from a broad array of information sources (Aladağ, 2003, p. 8). Teachers are no longer sources of information, but have rather focused their efforts on how and where to use the information, studying its relation with the needs of the individual, society and humanity, its conformance with the requirements of the current age and the society, and render life valuable for all humanity. This, in turn, brings up the issue of quality for the profession of teaching (Duman, 1991, p. 268).

It is the teacher who will manage the education system and teach individuals. The duty expected from a teacher is to plan and engage in educational and training activities 
that will contribute to bringing up individuals with universal knowledge, values, skills and manners in line with societal expectations and the goals of the Turkish national education. Teachers should be able to adept themselves to the social and technological developments while doing so (Baki, 2009, p. 62). This adaptation can help generate a readily available and sustainable qualified human resource, through which nations can achieve happiness and prosperity. Teacher is the most crucial person in providing individuals with the insight brought about by the shifting needs of nations necessary for sustaining a happy and prosperous existence, and teaching the ways to utilize this insight (Kaya, 2014).

Since teachers constitute one of the most fundamental components of the education system, the problems they are faced with certainly have a direct impact on the education system. As a natural result, teachers struggling with problems will not be able to make the desired contribution to the structure and mechanism of the education system. 294). Moreover, having to perform their professions in such difficult conditions causes teachers to lose their faith in their professions (Gömleksiz, Ülkü, Biçer and Yetkiner, 2010; Sar1 and Altun, 2015, p. 213). Like all other teachers, geography teachers, too, perform their duties in accordance with the principles and objectives set out by the Ministry of National Education, and during which they are confronted with various professional problems (Şahin, 2001, p. 60).

It is a fact that in Turkey, the profession of teaching is carried out under difficult conditions, and it is a fact that everybody agrees on a neutral side. During the literature review about teacher education problems in Turkey, there can be found many studies on teachers ' problems like (MEB, 1982; MEB, 1982a; Tekışık, 1986; Afşin, 1988; Güler, 1999; Yapıcı, 2003; Taneri, 2004; Maraş11, 2007; Karabulut, 2007; Aydın, 2008; Aydın, 2009; Bozpolat, 2009; Ekinci, 2010; Artvinli, 2010a, 2010b; Sarı, 2011; Geçer ve Özel, 2012; Demir ve Ar1, 2013; Polat, 2014; Öztürk, Kaya ve Durmaz, 2015), many studies have been carried out on geography teaching and problems. When these studies are examined, the titles are drawn attention like "Geography teaching and problems in higher education institutions during the Republican period" of Koçman (1999), Kayan (2000)'s "geography Education in Turkish universities", Şahin (2001)'s "a research on the Vocational problems of secondary education teachers" and Şahin (2003)'s "geography teaching in Turkey", problems and solutions", "the effectiveness and problems of Geography Education" of Akınoğlu (2005); "the satisfaction of the work of the Geography teachers in secondary education institutions" of Duman (2006); "the problems of geography education in teacher education in Turkey" of Gökçe (2009); "the stress resources of the Geography teachers" in Kaya and Alım (2015), but a study on the problems experienced by Geography teachers during the practice of their profession could not be reached.

The primary question underlying this study is that "To what extent the undergraduate education received by the geography teachers meets the knowledge and skills necessary during their professional life in Turkey?". To answer this question, the following subproblems were addressed: 
1- What is your opinion about the sufficiency level of the geography education received by the geography teachers during their undergraduate education?

2- What is the quality of in-service training required by the geography teachers in addition to their undergraduate education in order to provide more qualified geography education?

3- Does the sufficiency level of the geography education received by the geography teachers during their undergraduate education vary by various factors?

\section{Methodology}

\section{Research Design}

Qualitative research method was used in this study, which is a technique that allows regular analysis of the opinions drawing from individuals' experiences that have been or planned to be realized (Ekiz, 2003; Beldağ ve Geçit, 2017, p. 102). The individuals, objects or events to be analyzed are described in their own conditions (Karasar, 2012). In the qualitative studies, three types of data related to environment, process and perception is collected (Yıldırım and Şimşek, 2013).

\section{Participants}

This study is limited to the views of 212 geography teachers serving in 9 different provinces of Turkey. The opinions identified in the study and the proposed suggestions are limited to these geography teachers.

The principles that must be considered in determining the sample size are; the focus of the study, the amount of data, and institutional sampling (Y 1ldırım and Şimşek, 2006, p. 114). For that reason, with a purposeful and easily accessible sampling approach, 212 geography teachers, who could be reached from among the 680 teachers giving geography lessons in Adryaman, Ankara, Antalya, Artvin, Denizli, Isparta, İzmir, Kahramanmaraş and Trabzon in Turkey, participated in the study Demographic information of the geography teachers who participated in the study was given on Table 1.

Table 1

Demographic Characteristics of Geography Teachers

\begin{tabular}{llll}
\hline Characteristics & Dimensions & $f$ & \% \\
\hline \multirow{2}{*}{ Gender } & Female & 78 & 36.8 \\
& Male & 134 & 63.2 \\
\hline \multirow{4}{*}{ Age Group } & Younger than 25 & 2 & 0.9 \\
& $26-30$ & 18 & 8.5 \\
& $31-35$ & 27 & 12.8 \\
\multirow{3}{*}{ Working experience } & 36 and older & 165 & 77.8 \\
(year) & $0-10$ & 12 & 5.7 \\
& $11-15$ & 36 & 16.7 \\
& $16-20$ & 32 & 15.1 \\
& & 40 & 18.9 \\
\hline
\end{tabular}


Kaya, N. (2019). Linking the Learning and Teaching Geography: The Gap between School and University

\begin{tabular}{|c|c|c|c|}
\hline & $21-25$ & 62 & 29.2 \\
\hline & 26 and more & 30 & 14.4 \\
\hline \multirow{4}{*}{ School Types } & $\begin{array}{l}\text { Science and Social Sciences } \\
\text { High School }\end{array}$ & 10 & 4.7 \\
\hline & Anatolian High School & 98 & 46.2 \\
\hline & Imam-Hatip High School & 42 & 19.8 \\
\hline & Vocational High School & 62 & 29.3 \\
\hline \multirow{5}{*}{ Graduate Level } & $\begin{array}{l}\text { Training Institute or Bachelor's } \\
\text { Completed }\end{array}$ & 18 & 8.5 \\
\hline & Undergraduate & 130 & 61.3 \\
\hline & Master's Degree & 62 & 29.3 \\
\hline & Doctorate Degree & 2 & 0.9 \\
\hline & Total & 212 & 100 \\
\hline
\end{tabular}

According to the table, all of the geography teachers serve in the Ministry of National Education (MEB). 78 of the geography teachers were females and 134 were males. Their professional seniority ranges between 1 year and 36 years. Of the geography teachers who participated in the study, 36 serves in İzmir, 31 in Kahramanmaraş, 27 in Antalya, 27 in Isparta, 22 in Denizli, 21 in Ankara, 19 in Adiyaman, 15 in Trabzon an 14 in Artvin. Of the geography teachers who participated in the study, 46.2\% serve in Anatolian High School, 29.3\% in Vocational High School, $19.8 \%$ in Imam Hatip High School, and $4.7 \%$ in Science and Social Sciences High School. Of the geography teachers who participated in the study, $61.3 \%$ had Undergraduate, $29.3 \%$ had Master's, $8.5 \%$ had Training Institute or Bachelor's completed, and $0.9 \%$ had Doctorate degrees.

Table 2

Distribution of the Geography Teachers Who Participated in the Study According to the Provinces They Serve

\begin{tabular}{clcc}
\hline No & City & Frequency $(\mathbf{F})$ & Percentage ( \% ) \\
\hline 1 & Adiyaman & 19 & 8.9 \\
\hline 2 & Ankara & 21 & 9.9 \\
\hline 3 & Antalya & 27 & 12.7 \\
\hline 4 & Artvin & 14 & 6.6 \\
\hline 5 & Denizli & 22 & 10.4 \\
\hline 6 & İzmir & 36 & 17.0 \\
\hline 7 & Isparta & 27 & 12.7 \\
\hline 8 & Kahramanmaraş & 31 & 14.7 \\
\hline 9 & Trabzon & 15 & 7.1 \\
\hline & Total & $\mathbf{2 1 2}$ & $\mathbf{1 0 0}$
\end{tabular}

\section{Data Collection Tool}

In the study, an "Undergraduate Geography Education Sufficiency Level" form drawn up by the researcher consisting of 28 questions based on secondary school geography program learning subjects and attainments to determine the thoughts and opinions of the geography teachers in the sample group (Annex 1). The five-point 
Likert scale (very insufficient, insufficient, partially sufficient, sufficient, very sufficient) was used to determine the sufficiency level of the undergraduate education received by the participants on the relevant form.

\section{Collection and Analysis of Data}

Before moving on to the data analysis phase of the study, the filled-out forms were assigned scale numbers from 1 to 212 . The answers given by teachers to each item were analyzed through grounded theory and constant comparison analysis methods that are used for data analysis in qualitative studies.

This part of the study consists of the findings regarding the problems the geography teachers, who participated in the study in line with the main objective of the study, have with the school administration, teachers, students and parents as well as the answers they gave for the proposed solutions. The obtained data was explained and interpreted in the form of tables. The findings were listed under five main headings in accordance with the sub-problems of the study.

\section{Findings}

In this section, there are findings about the training needs of the geography teachers who participated in the study to get more qualified geography education by determining the level of education they receive during their undergraduate education level. The obtained data was explained and interpreted in the form of tables.

\section{The Sufficiency Level of the Undergraduate Geography Education According to the Teachers}

This section aimed to determine the level of satisfaction of geography during their undergraduate education.

Table 3

General Qualification Level of Geography Undergraduate Education

\begin{tabular}{rllllll}
\hline $\begin{array}{l}\text { What is the Level of } \\
\text { Qualification of Education in }\end{array}$ & $\mathbf{F}$ & $\mathbf{\%}$ & $\mathbf{X}$ & $\mathbf{S S}$ & Kurtosis & Skewness \\
Geography Education and & & & & & & \\
$\begin{array}{r}\text { Training Throughout your } \\
\text { Undergraduate Education? }\end{array}$ & & & & & & \\
\hline Very Poor & 12 & 5.7 & & & & \\
\hline Insufficient & 50 & 23.6 & & & & \\
\hline Partially Enough & 76 & 35.8 & & & & \\
\hline Enough & 66 & 31.1 & & & & \\
\hline Very Sufficient & 8 & 3.8 & & & & \\
\hline Total & 212 & 100 & 3.05 & 1.04 & -0.5 & 0.1 \\
\hline
\end{tabular}

According to the evaluation based on the sufficiency level of the geography teachers' undergraduate education in terms of each subject, the relevant points to consider as follow: very insufficient in terms of developing children's critical ability (27.4\%); insufficient in terms of the patterns and networks of economic dependence around the 
world (39.6\%); partially sufficient in terms of the methods and techniques of geography education $(34.4 \%)$; sufficient in terms of the processes, forms and functions of human settlement (38.2\%); and very sufficient in terms of how the physical systems impact the human systems $(24.1 \%)$.

Table 4

10 Fields Relatively Considered as Very Insufficient in the Undergraduate Education Received by the Geography Teachers

\begin{tabular}{llll}
\hline & \multicolumn{1}{c}{ Qualification Criteria } & $\mathrm{F}$ & $\%$ \\
\hline 1 & Developing children's critical ability & 58 & 27.4 \\
\hline 2 & Developing children's problem-solving ability & 54 & 25.5 \\
\hline 3 & Communication and empathy with children & 50 & 23.6 \\
\hline 4 & Developing children's proper, good and effective land use ability & 48 & 22.6 \\
\hline 5 & How to use geography to interpret the present and plan the future & 47 & 22.2 \\
\hline 6 & Characteristics of ecosystems and biomes and spatial distribution & 46 & 21.7 \\
\hline 7 & Characteristics, distribution and diversity of civilizations & 44 & 20.8 \\
\hline 8 & Using assessment and evaluation methods & 41 & 19.3 \\
\hline 9 & Project development techniques in geography education & 40 & 18.9 \\
\hline 10 & Providing active learning environments in geography education & 36 & 16.7 \\
\hline
\end{tabular}

According to the evaluation based on the sufficiency level of the geography teachers' undergraduate education in terms of each subject, the relevant points to consider as follow: very insufficient in terms of developing children's critical ability (27.4\%); insufficient in terms of the patterns and networks of economic dependence around the world $(39.6 \%)$; partially sufficient in terms of the methods and techniques of geography education $(34.4 \%)$; sufficient in terms of the processes, forms and functions of human settlement $(38.2 \%)$; and very sufficient in terms of how the physical systems impact the human systems $(24.1 \%)$.

According to the evaluation based on the sufficiency level of the geography teachers' undergraduate education in terms of each subject, the relevant ten "very insufficient" points to consider as follow (see Table 4): developing children's critical ability (27.4\%); developing children's problem-solving ability (25.5\%); communication and empathy with children $(23.6 \%)$; developing children's proper, good and effective land use ability $(22.6 \%)$; how to use geography to interpret the present and plan the future (22.2\%); characteristics of ecosystems and biomes and spatial distribution (21.7\%); characteristics, distribution and diversity of civilizations (20.8\%); using assessment and evaluation methods (19.3\%); project development techniques in geography education $(18.9 \%)$; and providing active learning environments in geography education (16.7\%).

Table 5

10 Fields Relatively Considered as Insufficient in the Undergraduate Education Received by the Geography Teachers

\begin{tabular}{llll}
\hline & Qualification Criteria & F & $\%$ \\
\hline 1 & Patterns and networks of economic dependence around the world & 84 & 39.6 \\
\hline 2 & Characteristics, distribution and diversity of civilizations & 75 & 35.4 \\
\hline
\end{tabular}




\begin{tabular}{llrr}
\hline 3 & Characteristics of ecosystems and biomes and spatial distribution & 74 & 34.9 \\
\hline 4 & $\begin{array}{l}\text { The impact of cooperation and conflict among people on the } \\
\text { distribution and control of the earth }\end{array}$ & 73.4 \\
\hline 5 & $\begin{array}{l}\text { The impact of the culture and experience on the people's perception of } \\
\text { places and regions }\end{array}$ & 71 & 33.5 \\
\hline 6 & Developing children's proper, good and effective land use ability & 67 & 31.6 \\
\hline 7 & How to use geography to interpret the present and plan the future & 64 & 30.2 \\
\hline 8 & Communication and empathy with children & 62 & 29.2 \\
\hline 9 & Using assessment and evaluation methods & 60 & 28.3 \\
\hline 10 & $\begin{array}{l}\text { Activity designing techniques corresponding the attainments in the } \\
\text { curriculum of geography education }\end{array}$ & 59 & 27.8 \\
\hline
\end{tabular}

According to the evaluation based on the sufficiency level of the geography teachers' undergraduate education in terms of each subject, the relevant ten insufficient points to consider as follow: patterns and networks of economic dependence around the world (39.6\%); characteristics, distribution and diversity of civilizations (35.4\%); characteristics of ecosystems and biomes and spatial distribution (34.9\%); impact of cooperation and conflict among people on the distribution and control of the earth (34.4\%); impact of the culture and experience on the people's perception of places and regions (33.5\%); developing children's proper, good and effective land use ability (31.6\%); how to use geography to interpret the present and plan the future $(30.2 \%)$; communication and empathy with children (29.2\%); using assessment and evaluation methods $(28.3 \%)$; and activity designing techniques corresponding the attainments in the curriculum of geography education $(27.8 \%)$.

According to the evaluation based on the sufficiency level of the geography teachers' undergraduate education in terms of each subject, as the very insufficient and insufficient ones considered together, the top ten points to consider respectively as follow: characteristics of ecosystems and biomes and spatial distribution (56.6\%); characteristics, distribution and diversity of civilizations $(56.2 \%)$; developing children's critical ability (54.8\%); patterns and networks of economic dependence around the world (54.7\%); developing children's proper, good and effective land use ability (54.2\%); communication and empathy with children (52.8\%); how to use geography to interpret the present and plan the future (52.4\%); developing children's problem-solving ability (50.5\%); impact of the culture and experience on the people's perception of places and regions (49.6\%); and using assessment and evaluation methods (47.6\%).

Table 6

10 Fields Relatively Considered as Partially Sufficient in the Undergraduate Education Received by the Geography Teachers

\begin{tabular}{llll}
\hline & \multicolumn{1}{c}{ Qualification Criteria } & F & $\%$ \\
\hline 1 & Effective teaching methods and techniques in geography education & 73 & 34.4 \\
\hline 2 & $\begin{array}{l}\text { Effective use of information-communication technologies in } \\
\text { geography education }\end{array}$ & 68 & 32.1 \\
\hline 3 & Developing children's problem-solving ability & 65 & 30.8 \\
\hline
\end{tabular}


Kaya, N. (2019). Linking the Learning and Teaching Geography: The Gap between School and University

\begin{tabular}{llrr}
\hline \hline 4 & $\begin{array}{l}\text { Developing children's accurate, proper and effective land use } \\
\text { ability }\end{array}$ & 65 & 30.8 \\
\hline 5 & Implementing the curriculum of geography education & 64 & 30.2 \\
\hline 6 & $\begin{array}{l}\text { Ability to use the maps and other geographical elements, } \\
\text { geographical technologies and spatial thinking in order to } \\
\text { comprehend and transfer the information }\end{array}$ & 61 & 28.8 \\
& $\begin{array}{l}\text { Ability to distinguish the physical and human characteristics of } \\
\text { spaces }\end{array}$ & 61 & 28.8 \\
\hline 8 & $\begin{array}{l}\text { Changes resulted from the meaning, using, distribution and } \\
\text { importance of natural resources }\end{array}$ & 61 & 28.8 \\
\hline 9 & $\begin{array}{l}\text { The impact of cooperation and conflict among people on the } \\
\text { distribution and control of the earth }\end{array}$ & 60 & 28.3 \\
\hline 10 & Characteristics of ecosystems and biomes and spatial distribution & 58 & 27.4 \\
\hline
\end{tabular}

According to the evaluation based on the sufficiency level of the geography teachers' undergraduate education in terms of each subject, the relevant ten partially insufficient points to consider as follow: methods and techniques of geography education (34.4\%); effective use of information and communication technologies in geography education (32.1\%); developing children's problem-solving ability (30.8\%); developing children's proper, good and effective land use ability (30.8\%); ability to use the maps and other geographical elements, geographical technologies and spatial thinking in order to comprehend and transfer the information (28.8\%); ability to distinguish the physical and human characteristics of spaces $(28.8 \%)$; changes resulted from the meaning, using, distribution and importance of natural resources (28.8\%); impact of cooperation and conflict among people on the distribution and control of the earth (28.3\%); and characteristics of ecosystems and biomes and spatial distribution (27.4\%).

Table 7

10 Fields Relatively Considered as $\underline{\text { Sufficient }}$ in the Undergraduate Education Received by the Geography Teachers

\begin{tabular}{llll}
\hline \multicolumn{1}{c}{ Qualification Criteria } & F & $\%$ \\
\hline 1 & The process, form and function of settlement & 81 & 38.2 \\
\hline 2 & Using the classroom equipments effectively in geography education & 71 & 33.5 \\
\hline 3 & How people's actions change the physical environment & 70 & 33.1 \\
\hline 4 & $\begin{array}{l}\text { Characteristics, distribution and migration of human populations on } \\
\text { the surface of the earth }\end{array}$ & 62 & 29.2 \\
\hline 5 & Ability to distinguish the physical and human characteristics of spaces & 62 & 29.2 \\
\hline 6 & How the physical systems impact the human systems & 58 & 27.4 \\
\hline 7 & How the people organize the spaces and surface of the earth & 57 & 26.9 \\
\hline 8 & Physical processes forming the surface of the earth & 55 & 25.9 \\
\hline 9 & $\begin{array}{l}\text { How the areas created by people in various places around the earth } \\
\text { with distinct characteristics emerged }\end{array}$ & 53 & 25.0 \\
\hline 10 & Providing active learning environments in geography education & 52 & 24.6 \\
\hline
\end{tabular}


According to the evaluation based on the sufficiency level of the geography teachers' undergraduate education in terms of each subject, the relevant ten sufficient points to consider as follow: processes, forms and functions of human settlement (38.2\%); using the classroom equipments effectively in geography education $(33.5 \%)$; how people's actions change the physical environment (33.1\%); characteristics, distribution and migration of human populations on the surface of the earth (29.2\%); ability to distinguish the physical and human characteristics of spaces $(29.2 \%)$; how the physical systems impact the human systems $(27.4 \%)$; how the people organize the spaces and surface of the earth (26.9\%); physical processes forming the surface of the earth (25.9\%); how the areas created by people in various places around the earth with distinct characteristics emerged (25\%); and providing active learning environments in geography education $(24.6 \%)$.

Table 8

10 Fields Relatively Considered as Very Sufficient in the Undergraduate Education Received by the Geography Teachers

\begin{tabular}{llll}
\hline & \multicolumn{1}{c}{ Qualification Criteria } & F & $\%$ \\
\hline 1 & How the physical systems impact the human systems & 51 & 24.1 \\
\hline 2 & The processes, forms and functions of settlement & 42 & 19.8 \\
\hline 3 & How people's actions change the physical environment & 40 & 18.9 \\
\hline 4 & How the people organize the spaces and ground & 40 & 18.9 \\
\hline 5 & $\begin{array}{l}\text { Effective use of information-communication technologies in } \\
\text { geography education }\end{array}$ & 35 & 16.5 \\
\hline 6 & Ability to distinguish the physical and human characteristics of spaces & 34 & 16.1 \\
\hline 7 & Physical processes forming the surface of the earth & 34 & 16.1 \\
\hline 8 & $\begin{array}{l}\text { How the areas created by people in various places around the earth } \\
\text { with distinct characteristics emerged }\end{array}$ & 31 & 14.6 \\
\hline 9 & Implementing the curriculum of geography education & 30 & 14.1 \\
\hline 10 & $\begin{array}{l}\text { Changes resulted from the meaning, using, distribution and } \\
\text { importance of natural resources }\end{array}$ & 28 & 13.2 \\
\hline
\end{tabular}

According to the evaluation based on the sufficiency level of the geography teachers' undergraduate education in terms of each subject, the relevant ten "very sufficient" points to consider as follow (see Table 8): how the physical systems impact the human systems $(24.1 \%)$; processes, forms and functions of human settlement $(19.8 \%)$; how people's actions change the physical environment (18.9\%); how the people organize the spaces and surface of the earth (18.9\%); effective use of information and communication technologies in geography education (16.5\%); ability to distinguish the physical and human characteristics of spaces (16.1\%); physical processes forming the surface of the earth $(16.1 \%)$; how the areas created by people in various places around the earth with distinct characteristics emerged (14.6\%); implementing the curriculum of geography education (14.1\%); and changes resulted from the meaning, using, distribution and importance of natural resources (13.2\%). 
According to the evaluation based on the sufficiency level of the geography teachers' undergraduate education in terms of each subject, as the very sufficient, sufficient and very insufficient ones considered all together, the top ten points to consider respectively as follow: processes, forms and functions of human settlement $(83.5 \%)$; how people's actions change the physical environment (77.5\%); how the physical systems impact the human systems (77\%); ability to distinguish the physical and human characteristics of spaces $(74.1 \%)$; how the people organize the spaces and surface of the earth $(73.2 \%)$; implementing the curriculum of geography education $(69.4 \%)$; effective use of information and communication technologies in geography education (67.9\%); characteristics, distribution and migration of human populations on the surface of the earth $(67.9 \%)$; how the areas created by people in various places around the earth with distinct characteristics emerged (67.4\%); and using the classroom equipments effectively in geography education (66\%).

Table 9

T-test results of total scores of geography education proficiency level according to gender

\begin{tabular}{ccccccc}
\hline & Gender & $\mathbf{N}$ & $\overline{\mathbf{X}}$ & SS & $\boldsymbol{t}$-value & p- value \\
\hline \multirow{3}{*}{ CEYDTP } & Male & 138 & 3.03 & 1.02 & -.31 & .75 \\
\hline
\end{tabular}

P.s: *p< 0.05; CEYDTP: Total Score of Geography Education Proficiency Level

When Table 9 is examined, it is found that there is no meaningful difference according to gender in terms of qualification level of geography education received by geography teachers during their undergraduate education. ( $\mathrm{p}>0.05)$.

Table 10

One-Way Variance Analysis of Total Scores of Geography Education Proficiency Level According To School Type Results

\begin{tabular}{lcccccc}
\hline Dimension & $\begin{array}{c}\text { School } \\
\text { Type }\end{array}$ & N & X & SS & F & p \\
\hline & 1 & 9 & 3.44 & 0.88 & 1.24 & .29 \\
\cline { 2 - 6 } CEYDTP & 2 & 109 & 2.94 & 1.10 & & \\
\cline { 2 - 6 } & 3 & 34 & 3.02 & 0.99 & & \\
\cline { 2 - 6 } & 4 & 58 & 3.20 & 0.95 & & \\
\hline
\end{tabular}

P.s: *p< 0.05; CEYDTP: Total Score of Geography Education Proficiency Level

According to table 10, the total score of the geography education that the geography teachers received during their undergraduate education is not significantly different from that of the school type. [ $\mathrm{f}=1.24 \mathrm{p}>0.05]$. 
Table 11

One way analysis of variance according to diploma scores of total scores of geography education proficiency level

\begin{tabular}{lcccccc}
\hline Dimension & Diploma & $\mathbf{N}$ & $\mathbf{X}$ & $\mathbf{S S}$ & $\mathbf{F}$ & $\mathbf{p}$ \\
\hline \multirow{3}{*}{ CEYDTP } & 1 & 19 & 3.21 & 1.08 & 0.51 & .60 \\
\cline { 2 - 6 } & 2 & 133 & 3.00 & 1.02 & & \\
\cline { 2 - 6 } & 3 & 58 & 3.12 & 1.06 & & \\
\hline
\end{tabular}

P.s: *p< 0.05; CEYDTP: Total Score of Geography Education Proficiency Level

According to table 11, there is no significant difference in the diploma variable of the total score of the geography education proficiency level taken by the geography teachers during their undergraduate education. $[\mathrm{f}=0.51 \mathrm{p}>0.05]$.

Table 12

Quality of in-Service Training required by the Geography Teachers

\begin{tabular}{|c|c|c|c|}
\hline & Quality & $\mathrm{F}$ & $\%$ \\
\hline 1 & Qualified teacher training & 54 & 6.3 \\
\hline 2 & Qualified curriculum & 57 & 6.6 \\
\hline 3 & Qualified textbook & 45 & 5.2 \\
\hline 4 & School and student level training & 26 & 3.0 \\
\hline 5 & The curriculum should be simplified & 8 & 0.9 \\
\hline 6 & Geography classrooms should be created & 69 & 8.0 \\
\hline 7 & Field work should be done & 114 & 13.3 \\
\hline 8 & Applied education & 62 & 7.2 \\
\hline 9 & $\begin{array}{l}\text { Activities that strengthen the professional development of } \\
\text { teachers }\end{array}$ & 32 & 3.7 \\
\hline 10 & Different curriculum by school types & 32 & 3.7 \\
\hline 11 & Technology-based learner-centred applied education & 47 & 5.5 \\
\hline 12 & Schools should be technically improved & 15 & 1.7 \\
\hline 13 & $\begin{array}{l}\text { Basic level of Education ( 6-14 years ) qualified geography } \\
\text { education should be given }\end{array}$ & 61 & 7.1 \\
\hline 14 & Must have qualified ancillary materials & 27 & 3.1 \\
\hline 15 & Lesson hours should be increased & 41 & 4.8 \\
\hline 16 & Tools and equipment needs should be met & 53 & 6.2 \\
\hline 17 & $\begin{array}{l}\text { The number of students in the class should be less than } 24 \\
\text { persons. }\end{array}$ & 21 & 2.4 \\
\hline 18 & $\begin{array}{l}\text { Teachers ' authority and responsibilities should be } \\
\text { increased }\end{array}$ & 51 & 5.9 \\
\hline \multirow[t]{2}{*}{19} & $\begin{array}{l}\text { Special material for geography education should be } \\
\text { developed }\end{array}$ & 37 & 4.3 \\
\hline & Total & 852 & 100 \\
\hline
\end{tabular}


According to table 12, the responses given by the geography teachers to the quality of the in-service training required by them are shown to be in-service training for land work (13.3\%). The most required lessons should be given geography education at an early age with $7 \%$ respectively, and Applied Geography education should be given as well as $7 \%$.

\section{Results and Discussion}

In this study carried out with the aim to determine the level of sufficiency of the undergraduate education received by the geography teachers working in the official education institutions under the Ministry of National Education (MoNE) in Turkey, 12 of the total 212 geography teachers $(5.7 \%)$ stated that their education is very insufficient, 50 of them (23.6\%) stated that it is insufficient, 76 of them (35.8\%) stated that it is partially sufficient, 66 of them $(\% 31.1 \%)$ stated that it is sufficient while 8 of them $(3.8 \%)$ stated that it is very sufficient. $29.4 \%$ of the geography teachers participated in the study, considered their undergraduate education as insufficient, $35.8 \%$ of them considered as partially sufficient, and $34.9 \%$ considered as sufficient. As only $35 \%$ of the geography teachers consider their undergraduate education as sufficient and very sufficient, it can be interpreted that about $2 / 3$ of the teachers consider that the undergraduate education they received is not sufficient.

According to the results of the scale developed based on the secondary geography education curriculum and attainments in order to determine the sufficiency level of the undergraduate education for geography teachers, the teachers consider their undergraduate education as very sufficient and sufficient in terms of how the physical systems impact the human systems (51.5\%); the processes, forms and functions of settlement (58\%); how people's actions change the physical environment (52\%); how the people organize the spaces and ground (45.8\%); physical processes forming the surface of the earth (16.1\%); effective use of information and communication technologies (35.8\%); implementing the curriculum of education $(38.6 \%)$; how the areas created by people in various places around the earth with distinct characteristics emerged (39.6\%); and changes resulted from the meaning, using, distribution and importance of natural resources $(35.8 \%)$.

The study also reveals that geography teachers participated in the study stated that the undergraduate education they receive is partially sufficient in terms of effective methods and techniques in geography education (34.4\%); effective use of information and communication technologies in geography education (32.1\%); developing children's problem-solving ability (30.8\%); developing children's proper, good and effective land use ability (30.8\%); and implementing the curriculum of geography education $(30.2 \%)$.

120 of the geography teachers $(56.6 \%)$ considered their undergraduate education as insufficient and very insufficient in terms of characteristics of ecosystems and biomes and spatial distribution;.119 of them (56.2\%) in terms of characteristics, distribution and diversity of civilizations; 116 of them $(54.8 \%)$ in terms of developing children's critical ability; 116 of them $(54.8 \%)$ in terms of patterns and networks of economic dependence around the world; 115 of them $(54.2 \%)$ in terms of developing children's 
proper, good and effective land use ability; 112 of them $(52.8 \%)$ in terms of communication and empathy with children; 111 of them $(52.4 \%)$ in terms of how to use geography to interpret the present and plan the future; 107 of them $(49.6 \%)$ in terms of impact of the culture and experience on the people's perception of places and regions; 101 of them (47.6\%) in terms of using assessment and evaluation methods; and 98 of them $(46.3 \%)$ in terms of project development techniques in geography education.

When evaluating the results of the scale of sufficiency level provided by the geography teachers participated in the study as a whole, it is generally considered that the undergraduate education received by the geography teachers is insufficient in terms of providing the professional qualifications (knowledge, skill, attitude etc.) required for secondary school teaching; characteristics of ecosystems and biomes and spatial distribution; characteristics, distribution and diversity of civilizations; patterns and networks of economic dependence around the world; developing children's proper, good and effective land use ability; communication and empathy with children; how to use geography to interpret the present and plan the future; developing children's problemsolving ability; impact of the culture and experience on the people's perception of places and regions; using assessment and evaluation methods; project development techniques in geography education etc.

The undergraduate educations programs for geography teaching should be updated according to the needs by taking all the beneficiaries' opinions in order to effectively and actively implement the curriculum of geography education in the official secondary education institution under the Ministry of National Education and to make the students gain geography skills that the 21 st century entails. Moreover, the subjects of cultural geography, natural disasters and disaster management, population (demographics) and movement of migration (demographical changes), climate and climate change, plant geography, environmental geography, political geography, geopolitics and Turkey, economic geography and globalization should be included in the undergraduate education programs for geography teachers. The inclusion of these courses in undergraduate programs will ensure the provision of both a geography teacher training on undergraduate level in conformance with the geography education program, and an undergraduate education that is up to the standards of the IGU (International Geography Union) on international scale.

Also, the applied activities should be carried out for the geography teachers currently working under the Ministry of National Education in order to satisfy their professional needs primarily in terms of plant geography, cultural geography, globalization and economy, patterns and networks of economic dependence around the world, assessment and evaluation, project development techniques in geography education, communication and empathy with children, developing children's problem-solving ability, critical ability and proper, good and effective land use ability.

The evidence from this study also suggests that, as crucial parts of geography teachers' professional development, several practice-based in-service training activities for those teachers who teach in state schools can be organized. The content of these 
activities can include the following subjects; plant geography, globalization and economy: forms and network of economic dependence in the world, assessment and evaluation, project development techniques in geography education, communication with children and empathy, developing students' critical thinking and problem solving skills, and accurate, good and effective use of lands.

According to the responses given to the scale developed based on secondary education geography program and its achievements in order to determine the level of competence based on the field of education in geography teaching programs, the education of geography teachers in undergraduate education, effects of physical systems on human systems $(51,5 \%)$, processes, forms and functions of human settlements (58\%), how people's actions); physical processes that shape the world surface have evaluated the importance of information and communication technologies $(35,8 \%)$, the effective use of teaching programs $(38,6 \%)$, human and economic geography $(39,6 \%)$, the emergence of regions where people are formed in different parts of the globe $(35,8 \%)$, and the changes in the meaning, use, distribution and importance of natural resources $(35,8 \%)$.

Teachers who participated in the study expressed their education in undergraduate education, effective teaching methods and techniques in geography education $(34,4 \%)$, effective use of information and communication technologies $(32,1 \%)$, developing problem solving skills of children $(30,8 \%)$, developing children's ability to use the land correctly, beautiful and effective (30,8\%), implementation of the curriculum $(30,2 \%)$.

$120(56,6 \%)$ of the geography teachers, the features and spatial distribution of ecosystems and biomes on Earth; 119 of them $(56,2 \%)$ characteristics, distribution and differences of civilizations; 116 of them $(54,8 \%)$ develop children's critical skills; 116 of them $(54,8 \%)$ patterns and networks of world economic interdependence; 115 of them $(54,2 \%)$ develop children's ability to use the land correctly, beautiful and effective; $112(52,8 \%)$ communication with children and empathy; 111 of them $(52,4 \%)$ how to use geography to interpret today and plan the future; 107 of them $(50,5 \%)$ develop problem solving skills of children; 105 of them $(49,6 \%)$ how culture and experience affect people's perceptions of places and regions; $101(47,6 \%)$ using measurement and evaluation management; 98 of them $(46,3 \%)$ of the undergraduate education they received in geography education and project development were inadequate and very inadequate. Artvinli (2010) found similar findings that teachers generally are not satisfied with the university education in order to teach geography more effectively in high schools when they become geography teachers (Artvinli, 2010).

According to the findings of the data in the questionnaire, the teachers' views competency level scale according to the fields are evaluated as a whole, the education and training given in geography teacher undergraduate programs, teachers in secondary education institutions professions qualifications (knowledge, skills, attitudes, etc.), ecosystems and biomes on Earth and spatial distribution, characteristics, distribution and diversity of civilizations, patterns and networks of economic dependence in the 
world, children's ability to, communication and empathy with children, how to use geography to interpret today and plan the future, developing problem solving skills of children, how culture and experience affect perception of places and regions, using measurement and evaluation management, project development in geography education and teaching, etc. it can be said that there is not enough level in acquiring such areas.

Şahin (2003) analysed the secondary geography education programme. He found important problems in secondary school geography curriculum. In this matter, this finding supports the findings of (MEB, 1982; MEB, 1982a; Tekışık, 1986; Afşin, 1988; Varış, 1992; Güler, 1999; Yapıcı, 2003; Taneri, 2004; Maraşılı, 2007; Karabulut, 2007; Aydın, 2008; Aydın, 2009; Bozpolat, 2009; Ekinci, 2010; Sar1, 2011; Geçer \& Özel, 2012; Demir \& Ar1, 2013; Polat, 2014; Öztürk, Kaya \& Durmaz, 2015). There is no study to determine the level of meeting the needs of the geography teachers. (Engin, 2003; Küçükahmet, 2007; Çoban, 2010; Çoban, 2011; Meriç \& Tezcan, 2005; Tonda, 2012; Öğülmüş, 2014; Sert, 2014; Oflaz \& Altayl1, 2014; Hamsi, 2015; Y1lmaz, 2016). Although there are many studies on Bachelor's degree programs that raise teachers in different disciplines, the lack of studies on geography Bachelor's degree programs is considered to be an important deficiency.

\section{Suggestions}

Geography teachers ' responses to competency level scale according to the fields are evaluated as a whole, the education and training given in geography teacher undergraduate programs, teachers in secondary education institutions professions qualifications (knowledge, skills, attitudes, etc.), ecosystems and biomes on Earth and spatial distribution, characteristics, distribution and diversity of civilizations, patterns and networks of economic dependence in the world, children's ability to, communication and empathy with children, how to use geography to interpret today and plan the future, developing problem solving skills of children, how culture and experience affect perception of places and regions, using measurement and evaluation management, project development in geography education and teaching, etc. it can be said that there is not enough level in acquiring such areas.

Undergraduate geography teaching programs need to be updated on a need-based basis by taking the opinions of all stakeholders, to be able to apply the geography curriculum effectively and effectively and to provide the geographic skills required by the 21 st century to students. In addition, some suggestions can be made to the geography teachers who are currently working in the Ministry of National Education (MoNE) by developing application-based activities to meet the professional development needs in the areas they need.

Teacher education programs of geography cultural geography, disasters and disaster Management, population (demographics) and migration movements (demographic change), climate and climate change, plant geography, environmental geography, political geography, geopolitics and Turkey, economic geography, and globalization should be included in courses on. With the inclusion of these courses in degree programs, geography teacher training in accordance with geography education program 
will be given at undergraduate level and undergraduate education will be given at international level accepted by IGU (International Geographical Union).

In addition, the geography teachers who are currently working in MoNE, plant geography, cultural geography, globalization and economics: patterns and networks of economic dependence in the world, measurement and evaluation, project development techniques in geography and education, communication with children and empathy, problem solving, critical thinking and development of the correct, beautiful and effective use of the land, to meet the professional development.

\section{References}

Afşin, F. N. (1988). Stajyer ögrretmenlerin meslekle ilgili sorunlart ve çözüm yolları. Yayınlanmamış Yüksek Lisans Tezi, Hacettepe Üniversitesi Sosyal Bilimleri Enstitüsü, Ankara.

Akınoğlu, O. (2005). Coğrafya eğitiminin etkililiği ve sorunları. Marmara Coğrafya Dergisi, $12,77-96$.

Aladağ, C. (2003). Orta ögrretimde coğrafya öğretmeni profili ve öğretmen görüşleri ışı̆̆ında müfredat değerlendirilmesi (Konya ili örneği). Yayınlanmamış Doktora Tezi. Selçuk Üniversitesi. Konya.

Artvinli (2010). Coğrafya'da Öğretmen Eğitimi-Hizmet Öncesi-Hizmet İçi Eğitim İhtiyaç Analizi, Pegem Akademi Yayınc1lk, Ankara.

Artvinli, E. (2010a). Coğrafya Öğretmenlerinin Öğretme Stilleri, Elektronik Sosyal Bilimler Dergisi, Cilt: 9, Say1: 33, 387-408.

Artvinli, E. (2010b). "Challenges and Drivers in Front of the Geography Curriculum in Turkey", E-Journal of New World Sciences Academy, Education Sciences, 1C0249, 5, (4), pp. 1966-1983.

Aydın, B. (2004). 21. Yüzyllda eğitim ve Türk eğitim sistemi. İstanbul: Dem Yayınları.

Aydın, R (2009). Türkiye'de öğretmen sorunları açısından milli eğitim şuralarının değerlendirilmesi (1980-2000). Ankara Üniversitesi Eğitim Bilimleri Dergisi, 42(2), S. 119-237. Ankara.

Aydın, R. (2008). Türkiye'de eğitimle ilgili yapılan bilimsel toplantılarda ve millı̂ eğitim şûralarında ele alınan ögrretmen sorunları ile Millî Eğitim Bakanlığı'nın politika ve uygulamalarının değerlendirilmesi (1980-2004). Yayınlanmamış Doktora Tezi. Ankara Üniversitesi. Ankara

Baki, A. (2009). Türkiye'de alan öğretmeni yetiştirmede programlarının ve politikalarının değerlendirilmesi, eğitimde yansımalar: IX Türkiye'nin öğretmen yetiştirme çıkmazı ulusal sempozyumu, 12-13 Kasım 2009, Evren Yayıncılık A.Ş., Ankara.

Beldă̆, A. ve Geçit, Y (2017). Sosyal bilgiler öğretmenlerinin “coğrafya” kavramına ilişkin algıları: Bir olgubilim araştırması, Doğu Coğrafya Dergisi: 22(37), 99-112.

Bloom, B. S. (2012). İnsan nitelikleri ve okulda öğrenme. MEB Yayınları, İstanbul.

Bozpolat, E. (2009). Sinıf ögrretmenlerinin eğitim-öğretim sürecinde karşılaştıkları sorunlar, Cumhuriyet Üniversitesi Yayınlanmamış Yüksek Lisans Tezi, Sivas. 
Cansız. M. (2015) Coğrafya öğretmen adaylarının ortä̈ğretim coğrafya müfredatında yer alan coğrafya konularını öğretmedeki mesleki öz yeterlilik algıları, Yayınlanmamış Yüksek Lisans Tezi, Marmara Üniversitesi Eğitim Bilimleri Enstitisü, İstanbul.

Çoban, A. (2010). Türkçe öğretmenliği lisans programlarının değerlendirilmesi, Turkish Studies, 5(3), 958-976, Ankara.

Çoban, A. (2011). Sınıf öğretmenliği lisans programının değerlendirilmesi, Dicle Üniversitesi Ziya Gökalp Eğitim Fakültesi Dergisi, 16, 28-45, Diyarbakır.

Demir, M. K. \& Arı, E (2013). Öğretmen sorunları - Çanakkale ili örneği, Ondokuz Mayıs Üniversitesi Ĕgitim Fakültesi Dergisi, 32(1)107-126. Samsun.

Demir, Ö. \& Çamlı, Ö. (2011). Öğretmenlik uygulaması dersinde uygulama okullarında karşılaşılan sorunların sınıf ve okulöncesi öğretmenliği öğrenci görüşleri çerçevesinde incelenmesi: Nitel Bir Çalışma. Uludağ Üniversitesi Ĕ̈itim Fakültesi Dergisi, 24(1), 117- 139.

Duman, C. (2006). Ortaöğretim kurumlarında görev yapan coğrafya öğretmenlerinin iş tatmini. Yayınlanmamış Yüksek Lisans Tezi. Marmara Üniversitesi. İstanbul

Duman, T. (1991). Türkiye'de Orta ögretime ögretmen yetiştirme. İstanbul: MEB Yayınlar1, Bilim ve Kültür Eserleri Dizisi, Araştırma ve İnceleme Dizisi No: 20.

Ekinci, A. (2010). İlkögretim okullarda çalışan müdür ve öğretmenlerin mesleki sorunlarına ilişkin görüşleri. İlkögretim Online Dergisi, 9(2), 734-748.

Ekiz, D. (2003). Eğitimde araştırma yöntem ve metotlarına giriş. Ankara: Anı Yayıncılık.

Engin, A. O. (2003). Ingilizce öğretmeni yetiştiren örgün ve yaygın öğretim lisans programlarının karşılaştırılması, Yayımlanmamış Doktora Tezi, Atatürk Üniversitesi, Sosyal bilimler Enstitüsü, Erzurum.

Geçer, A \& Özel, R. (2012). İlköğretim fen ve teknoloji dersi öğretmenlerinin öğrenme-öğretme sürecinde yaşadıkları sorunlar. Kuram ve Uygulamada Eğitim Bilimleri, 12(3), 1-26.

Gökçe, N. (2009 ). Türkiye'de öğretmen yetiştirmede coğrafya eğitimin sorunları ve öneriler, Kuram ve Uygulamada Ë̆itim Bilimleri, 9(2) 721-768.

Güler. A. (1999). Cumhuriyet dönemi bazı süreli yayınlara yansıyan ögretmen sorunları (19291961). Yayınlanmamış Yüksek Lisans Tezi. Ankara Üniversitesi.

Hamsi, M. (2015). Türkiye ve Hollanda'daki İngilizce öğretmenliği lisans programlarının pedagojik alan bilgisi kazandırma açısından karşılaştırılması, Yayınlanmamış Yüksek lisans tezi, Ankara Üniversitesi. Eğitim Bilimleri Enstitüsü, Ankara.

Karabulut, A. O. (2007). Bilgisayar öğretmenlerinin okulda karşılaştıkları sorunların belirlenmesi, Yayınlanmamış Yüksek Lisans Tezi, Balıkesir Üniversitesi, Balıkesir.

Karasar, N. (2012). Bilimsel araştırma yöntemi. Ankara. Ankara, Nobel Yayın Dağıtım.

Kaya, F. \& Alim, M. (2015). Coğrafya öğretmenlerinin stres kaynakları. Doğu Coğrafya Dergisi, 20(34), 171-186, Erzurum.

Kaya, N. (2012). Türkiye'de coğrafya eğitimi, program, ders kitaplarl ve ögrretmen eğitimi boyutu. Yayınlanmamış Doktora Tezi. Gazi Üniversitesi. Ankara.

Kaya, N. (2014). Türkiye'de coğrafya öğretmeni yetiştirme ve istihdamı. Kastamonu Ë̆gitim Dergisi, 22(2), 783 - 806. 
Kaya, N. (2019). Linking the Learning and Teaching Geography: The Gap between School and University

Kayan, İ. (2000). Türkiye üniversitelerinde coğrafya eğitimi. Ege Coğrafya Dergisi, 11, 7-22.

Koçman, A. (1999). Cumhuriyet döneminde yükseköğretim kurumlarında coğrafya öğretimi ve sorunlar1. Ege Coğrafya Dergisi, 10, 1-14.

Küçükahmet, L. (2007). 2006-2007 öğretim yılında uygulanmaya başlanan öğretmen yetiştirme lisans programlarının değerlendirilmesi, Türk Ĕgitim Bilimleri Dergisi, 5(2), 203-218, Ankara

Maraşl1, Ş. (2007). Türkiye'de eğitimle ilgili süreli yayınlara yansıyan ögretmen sorunları. Yayınlanmamış Yüksek Lisans Tezi, Ankara Üniversitesi Eğitim Bilimleri Enstitisü, Ankara.

MEB (1982). On birinci milli eğitim şurast: Milli eğitim hizmetinde öğretmen ve eğitim uzmanları (durum ve sorunlar), Ankara: Milli Eğitim Matbaası.

MEB (1982a). Öğretmen sorunları ve ĕgilimleri araştırması. Ankara: Mesleki ve Teknik Açık Öğretim Okulu Matbaasi.

MEB (2017). 28 Kasım 2017 tarihli dilekçeye verilen yazılı cevap, Millî Eğitim Bakanlığ Strateji İnsan Kaynakları Genel Müdürlüğü, Ankara.

Meriç, G. ve Tezcan, R. (2005). Fen bilgisi öğretmeni yetiştirme programlarının örnek ülkeler kapsamında değerlendirilmesi (Türkiye, Japonya, Amerika ve İngiltere Örnekleri), Balıkesir Üniversitesi Fen bilimleri Enstitüsü Dergisi, 7(1), 62-82, Balıkesir.

Oflaz, G. \& Altayl1, D. (2014). An evaluation about teacher training programs: From the perspective of preservice teachers, The Eurasia Proceedings of Educational \& Social Sciences (EPESS), 1, 335-340.

Ögülmüş, K. (2014). Alan mezunu ve alan dışı lisans programlarından mezun özel eğitim ögretmenlerinin mesleki yeterliklerinin değerlendirilmesi, Yayımlanmamış Yüksek Lisans Tezi Necmettin Erbakan Üniversitesi, Eğitim Bilimleri Enstitüsü, Konya.

Öztürk, F., Kaya, N, ve Durmaz, E. (2015). Okul öncesi öğretmenlerinin görev sürecinde yaşadıkları eğitimsel sorunlar ve çözüm önerileri. Giresun Üniversitesi Karadeniz Sosyal Bilimler Dergisi, 7(2), 67-94. Giresun.

Polat, Ü. (2014). Mütarekeden cumhuriyete basında eğitim ve öğretmen sorunları (1918-1923). Yayımlanmamış Doktora Tezi, Ankara Üniversitesi, Ankara.

Sarı, M. H. \& Altun, Y. (2015). Göreve yeni başlayan sınıf öğretmenlerinin karşılaştıkları sorunlar. Hacettepe Üniversitesi Eğitim Fakültesi Dergisi [Hacettepe University Journal of Education], 30(1), 213-226. Ankara.

Sert, Z. (2014). Teknoloji ve tasarım dersine atanan ögretmenlerin mezun oldukları lisans programları ile alan yeterlilikleri arasındaki ilişkinin değerlendirilmesi: Güneydoğu Anadolu bölgesi örneği, Yayımlanmamış Yüksek Lisans Tezi, Gazi Üniversitesi Eğitim Bilimleri Enstitüsü, Ankara.

Sönmez, V. (1994). Program geliştirmede ögretmen el kitabı. Pegem Akademi Yayınları, Ankara.

Sünbül,A. M. (2001). Bir meslek olarak öğretmenlik. Öğretmenlik mesleğine girişs (Ed. Demirel, Ö ve Kaya, Z.) Ankara: PEGEMA yayıncılık. 223-254.

Şahin, C. (2001) Orta öğretim coğrafya öğretmenlerinin mesleki sorunları hakkında bir araştırma. Marmara Coğrafya Dergisi, 3(2), 59-70. 
Şahin, C. (2003). Türkiye'de coğrafya ögretimi, sorunları ve çözüm önerileri (2. bask1). Ankara: Gündüz Eğitim ve Yayıncılık.

Taneri, P. O. (2004). A study on novice classroom teacher's problems with regular alternative certificates, ODTÜ Yayınlanmamış Yüksek Lisans Tezi, Ankara.

Tekışık. H. H. (1986). Türkiye'de öğretmenlik mesleği ve sorunları. Çăgdaş Eğitim Dergisi, 11(116), 1-9.

Tonda, D. (2012). Sosyal bilgiler öğretmenliği lisans programının değerlendirilmesi, Türk Eğitim Bilimleri Dergisi, 10(4), 780-803.

Varış, F. (1988). Ĕgitimde program geliştirme, "teori ve teknikler”, Ankara Üniversitesi Eğitim Bilimleri Fakültesi Yayınları, Ankara.

Varış, F. (1999). "Yüzyılın sonunda öğretmen eğitimi sorunları". Anadolu Üniversitesi Eğitim Fakültesi Dergisi, 5(1-2), 19-28.

Yapıc1, M. \& Yapıcı, Ş. (2003). İlköğretim öğretmenlerinin karşılaştığı sorunlar. Üniversite ve Toplum, Bilim, Eğitim ve Düşünce Dergisi, 3(3).

Yıldırım. A. \& Şimşek, H. (2006). Sosyal bilimlerde nitel araştırma yöntemleri. (8.Baskı). Ankara: Seçkin Yayıncılık.

Yıldırım. A. \& Şimşek, H. (2011). Sosyal bilimlerde nitel araştırma yöntemleri. (8.Baskı). Ankara: Seçkin Yayıncılık.

Yıldırım. A. \& Şimşek, H. (2013). Sosyal bilimlerde nitel araştırma yöntemleri. Ankara: Seçkin Yayıncılik.

Yılmaz, O. (2016). Sosyal bilgiler ve fen bilgisi eğitimi lisans programlarının çevre eğitimi açısından değerlendirilmesi, Yayımlanmamış Yüksek Lisans Tezi, Ahi Evran Üniversitesi Sosyal Bilimler Enstitüsü, Kırşehir.

\section{Biographical Statement}

Niyazi KAYA is an education expert in Ministry of National Education in Ankara, Turkey. His academic focus in geographical education is in- service and pre-service education in geography, textbooks, curriculum development and assessment in geographical education. 